\title{
Susanne K Langer Virtual Space Concept On Wayang ukur Panakawan
}

\author{
Mohamad Yudisa Putrajip, Trie Hartiti Retnowati \\ \{ yudisaputrajip@gmail.com and tri_hartiti@yahoo.com \} \\ Yogyakarta State University, Indonesia
}

\begin{abstract}
Panakawan shadow puppet play is the reflection of Javanese philosophy of life. Panakawan figures are also a form of reflection that is dynamic and also contains a moral of life. In 1964 Sigit Sukasman made Panakawan Wayang ukur using a realistic measure of size. Sukasman analyzes the forms based on the analysis and making comparisons of the human body. Wayang measured, Sukasman's creation is extraordinary within Susanne's symbolic virtual space concept. K. Langer.
\end{abstract}

Keywords: Wayang ukur, Shadow Puppets Virtual Space, Langer.

\section{Introduction}

The essence of shadow puppets play is to tells the heroism of good-character figures facing evil character The fact that Shadow puppet play has gone through various historical events, from generation to generation this shows how puppet culture has been attached to and become part of Indonesian life. Such a long age and the fact that until this day there are still many people who love it shows how valuable and meaningful Shadow puppet play for people's lives $^{1}[1]$.

Panakawan shadow puppets play is popular in particular by the Javanese people and most of the Indonesian people. with all kinds Panakawan shadow puppets play details, is part of the performance of shadow puppets play which cannot be separated ${ }^{2}$ [2]. Panakawan is one group of figures with moral values that are very effective to be a guide for human life. Panakawan is also Javanese people source and reflection of the philosophy of life. Panakawan figures are also a form of reflection that is dynamic and also contains a moral message in life.

Shadow puppets play figures are not absolutely in one character, the figures do not just portray characters, but also portray characters. Shadow puppets play figures actually also depict the mood of the character depicted. However, because to portray the mood of the character is not only represented by hand movements, while other body parts such as eyes, mouth, shoulders, and waist cannot be moved so there are various.

${ }^{1}$ B. Sabunga, D. Budimansyah, and S. Sauri, "Nilai-nilai Karakter dalam Pertunjukan Wayang Golek Purwa," J. Sosio Reli., vol. 14, no. 1, pp. 1-13, 2016.

${ }^{2}$ S. M. Kushendrawati, "Wayang Dan Nilai- nilai Etis : Sebuah Gambaran Sikap Hidup Orang Jawa." 
Wayang ukur (kind of Shadow puppets play ) has very special elements design when viewed from an art point of view. The Wayang ukur exploration results realized in the form actually not just as artworks without meaning, but have a high aesthetic value. Ease of Use ${ }^{3}[3]$.

\section{Material \& Methodology}

\subsection{Data}

data is collected from various settings, methods and sources. In this study, the data was obtained using literature, review observation (interview), interview (interview), documentation, and combination (triangulation) techniques ${ }^{4}[4]$.

\subsection{Method}

This research is a qualitative research with a semiotic approach. Semiotics is the study of the sign of how the functioning of signs and production of the meaning of the signs can convey information so that it is communication ${ }^{5}[5]$. A sign is something that represents or describes something else (in the mind of someone who thinks about it).

\section{Results and Discussion}

\subsection{Wayang (shadow puppet) Ukur}

Wayang (shadow puppet) is Indonesian (Javanese) original word which means shadow or shadow that comes from a word that gets the prefix way into the word puppet ${ }^{6}[6]$. So the word puppet, which in the past means showing shadows. Gradually it became a shadow show, then became a shadow art or puppet show. Wayang ukurwas created by sigit spokesman in $1964^{7}$ [7]. Basically, the Wayang ukur is not different from the mostly shadow puppet play, except the color and inlay style. Inlay and transparent colors make a very beautiful and interesting work. Wayang ukuris also equipped with infrastructure that greatly accommodates the atmosphere of the staging scene. Supporters of various colorful lights can create a distinctive and special nuance. When viewed from the play the wayang ukur includes the leather puppet purwa, because it still originates from Mahabharata and Ramayana.

\footnotetext{
${ }^{3}$ Ribut Basuki, "Panakawan'S Discourse of Power in Javanese Shadow Puppet During the New Order Regime: From Traditional Perspective To New Historicism,” K@Ta, vol. 8, no. 1, pp. 68-88, 2006.

4 Sugiyono, Metode Penelitian Pendidikan (Pendekatan Kuantitatif, Kualitatif,dan R\&D). Bandung: Alfabeta, 2011.

${ }^{5}$ S. Tinarbuko, Semiotika Komunikasi Visual. Yogyakarta: Jalasutra, 2009

${ }^{6}$ S. Mulyono, Semar dan Filsafat Ketuhanan. Yogyakarta: Gelombang Pasang, 2005

${ }^{7}$ Sunarto, Seni Gatra Wayang Kulit Purwa. Yogyakarta: Dahara Prize, 1999
} 
Sukasman made Wayang ukur using realistic and sense size measurements of the human body, followed by making comparisons of the human body. Wayang ukur Sukasman's is an exploration of extraordinary forms. Made from the classic shadow puppet design, the Wayang ukur has its own characteristics from the form of sunggingan (coloring technique), sculpture, clothing, and ornaments, whose strength is transparency. This is certainly as a preservation so that wayang constantly exists and because wayang is meaningful, and is very effective education media, the depiction of life, and knowledge ${ }^{8}[8]$.

Sukasman made reform not only in the form of wayang but also in the presentation. Sukasman placed the pesinden facing the audience, the stage was set with the artistic scenery. Stage visualization on of the show was expanded with the placement of the lights that were taken into account the lighting so that the impression of color can change according to the desired. Lights for lighting are approximately 150 lights $^{9}$ [9]. Sukasman combines many wayang creations from various gagrags with the western modern art concepts which then performs individually and is widely known as the Wayang ukur. The design and the value of Wayang ukur of change in Purwa wayang kulit culture. The performance of the puppet shadow show whose presentation is adjusted to the demands of the changing times. Wayang ukur performance takes only two hours and not one but three or even four. Dhalang only plays puppets, the narrator is the one who plays the dialogue for each puppet character. Gamelan players in the puppet show about 20 musicians, and are very important in the performance. Gamelan or music used are slendro and pelog. To visualize the scene in the performance, not only with wayang, but Sukasman included elements of dance and puppet drama to visualize the puppet characters in the screen. With the sensational puppet show that is full of sensationalism, although it is true it has deviated far from the actual standard of wayang ${ }^{10}[8]$.

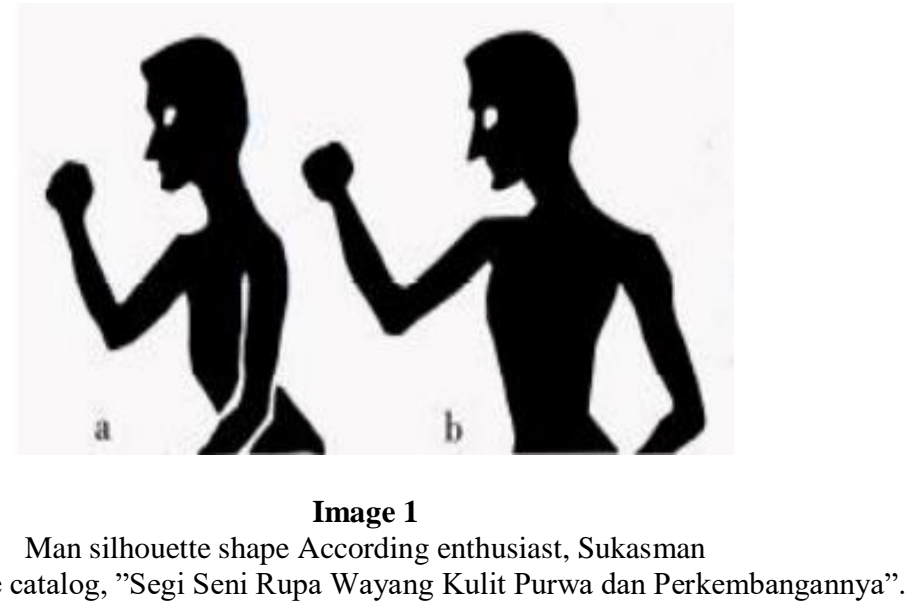

\footnotetext{
${ }^{8}$ E. Suyanto, S. Ve, and S. Tez, "Perbandingan Karakteristik Antara Tokoh Panakawan Wayang Kulit Purwa Gaya Yogyakarta Dengan Wayang Ukur Karya Sigit Sukasman,” Universitas Negeri Yogyakarta, Yogyakarta, 2012.

${ }^{9}$ S. Dosen, T. Akademi, D. Indonesia, and S. Email, "Wayang ukur karya sukasman studi ekplorasi bentuk," vol. 6, no. 1, pp. 78-93, 2011

${ }^{10}$ E. Suyanto, S. Ve, and S. Tez, "Perbandingan Karakteristik Antara Tokoh Panakawan Wayang Kulit Purwa Gaya Yogyakarta Dengan Wayang Ukur Karya Sigit Sukasman," Universitas Negeri Yogyakarta, Yogyakarta, 2012.
} 


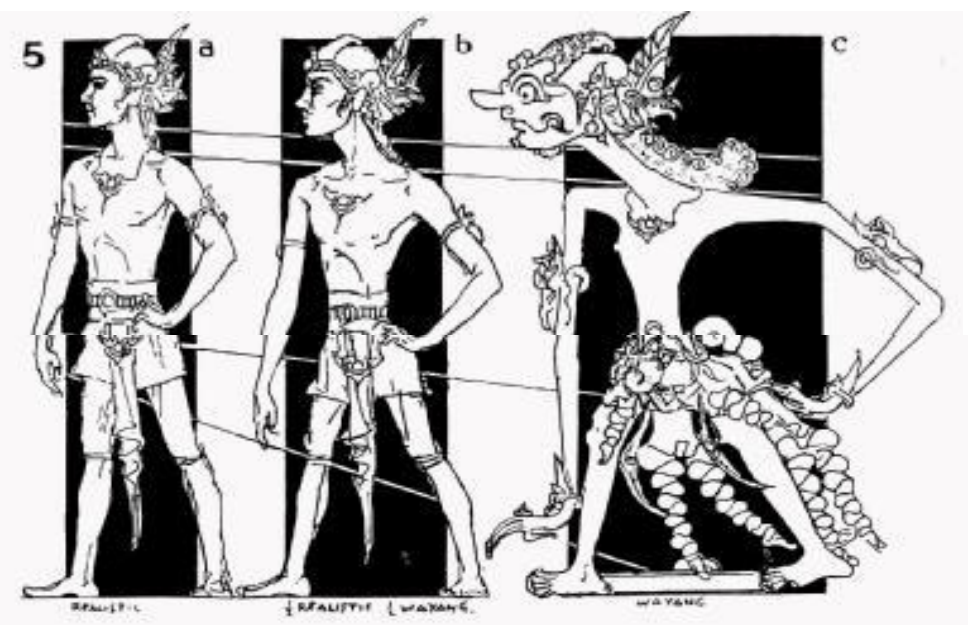

Image 2

The proportion body according Sukasman,

source : of the catalog, "Segi Seni Rupa Wayang Kulit Purwa dan Perkembangannya".

\subsection{Wayang ukur Panakawan}

Panakawan derived from Puna and Kawan. Puna means difficult; whereas kawan mean friends or relatives. So the meaning of Punakawan can also be translated by friends/relatives when difficult situations. Another interpretation of the words of Punakawan, Puna can also be called Pana which means light, while friend means friend or relative. So other interpretations of the meaning of the word Punakawan are friends or relatives who take to the bright path. So if combined then the meaning of the Semar figure, Nala Gareng, Petruk, Bagong means that 'hurry up do good, leave bad things ${ }^{11}[10]$.

Panakawan is from Indonesia, while Punakawan figures become the topic on this papper focused on Wayang ukur panakawan. Punakawan there are four of them, Gareng, Petruk and Bagong are made in such a way as to approach the diverse condition of the Javanese people, their characters indicate various roles, such as knights adviser, entertainers, social critics, clowns and even sources of truth and virtue ${ }^{12}[9]$.

\footnotetext{
${ }^{11}$ Senawangi, Ensiklopedi Wayang Indonesia. Jakarta: Balai Pustaka, 1999.

${ }^{12}$ S. Dosen, T. Akademi, D. Indonesia, and S. Email, "Wayang ukur karya sukasman studi ekplorasi bentuk," vol. 6, no. 1, pp. 78-93, 2011
} 


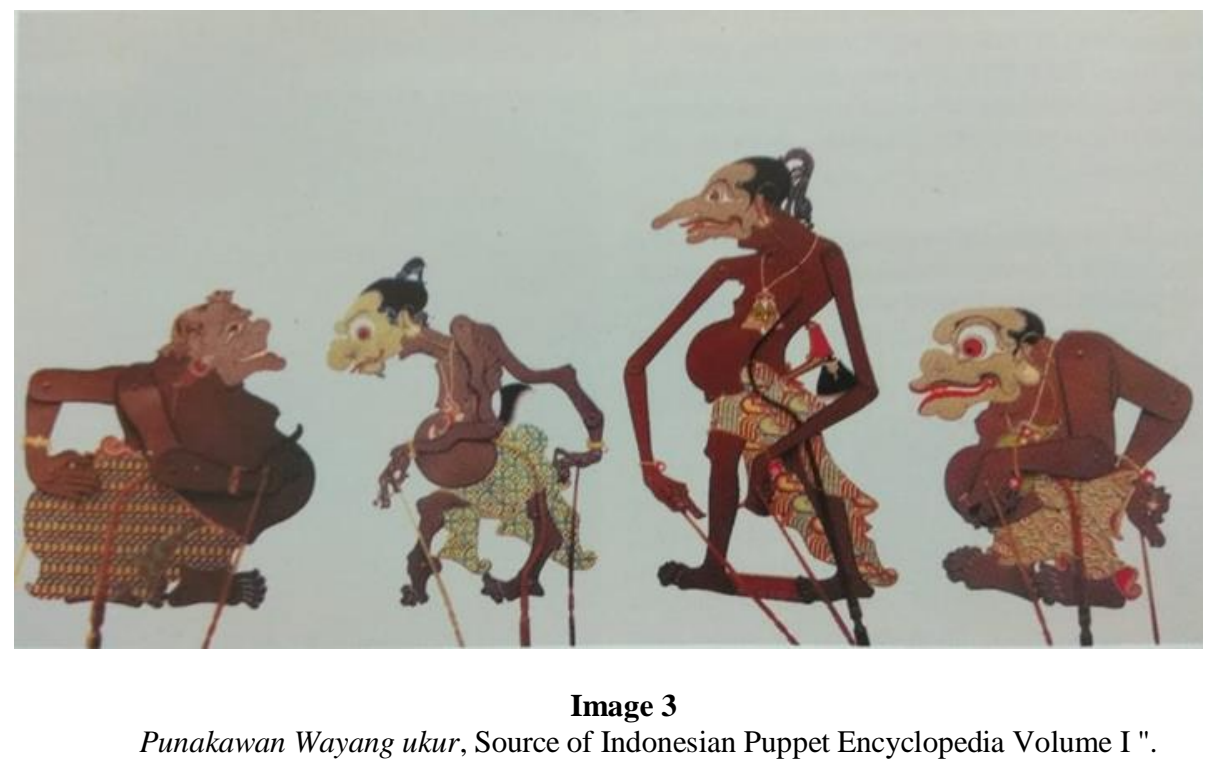

Wayang ukur panakawan has a different characteristic from the Panakawan puppet commonly. On Wayang ukur panakawan there is a nose, saliva coming out of the mouth, water that comes out of the nose "umbel" and on the puppet is common. The hand adjusted depending on what the situation is. The right hand and left hand are distinguished as well as the palm of the hand, but Semar on wayang kekayon does not know his right and left hand. The breasts are more vivid, the navel is made upwards but on Semar wayang kekayon the breasts are not too big, while the pusher is slightly closer to the foot. His stomach is bigger than his buttocks, but in Semar kekayon it is usually balanced, so it feels a little heavier in the front. His body is not too round. Clothes made free according to Sukasman's taste. The shape of the Gareng Wayang ukur the shape of its face distinguished in the eyes made full circle but Gareng wayang kekayon is rather oval. His body was thinner. The nose looks clear like eggplant and the nose is clearly visible in the basin but Gareng on wayang kekayon were not. The design of Wayang ukur Petruk its face size is on the nose, it seems clearly made longer and there is an arch. His head is smaller than Gareng wayang kekayon. His body was taller and thinner. The stomach looks more like a circle while. Puser petruk far from the foot while the Petruk wayang kekayon pusher reaches the foot. The design of the back until the buttocks resemble the letter $\mathrm{S}$. The hands are thinner and longer. The right hand and left hand are distinguished as well as the palm of the hand. The form of Bagong Wayang ukur the face and is distinguished from the nose which is made to pop out and there is a hollow above the nose. The mouth and chin are smaller and even the head is much smaller, and the head shape is varied. Hands bigger than Bagong wayang kekayon. His body was thinner. The shape of the back until the buttocks resemble the letter $\mathrm{S}$. The right hand and left hand are distinguished as well as the palm of the hand ${ }^{13}[8]$.

${ }^{13}$ E. Suyanto, S. Ve, and S. Tez, "Perbandingan Karakteristik Antara Tokoh Panakawan Wayang Kulit Purwa Gaya Yogyakarta Dengan Wayang Ukur Karya Sigit Sukasman,” Universitas Negeri Yogyakarta, Yogyakarta, 2012. 


\subsection{Wayang ukur Panakawan as Virtual Space}

According to Langer art is a creation. Art truly made entirely something from natural reality. Artwork is only accepted for vision, Susanne Langer explains it with the example of using a mirror, we can see ourselves as well as the space we occupy in the mirror, but cannot touch it. Such things are called virtuality, or illusion. Art works are images because we capture them through imagination. Artwork is a virtual object because it is present for the senses of sight. Art is an illusion, because even though the sense of sight captures its form, but not standing with the existence ${ }^{14}[11]$.

Wayang ukur panakawan is a physical form of a metaphysic. Where Wayang ukur is a virtual space (real space) of power or energy which metaphysical. The point is of Wayang ukur is a tangible form of the ideas that explained by symbol that not understand yet. Projection of various art forms as "secondary illusion". The primary illusion is called "primary" not because it was created first in the mind of the artist before the creation of secondary illusions, but because its function is always behind the secondary illusion.

Virtual space itself is a bridge of symbols that cannot be understood to be understood. Therefore, Wayang ukur panakawan explains the concepts of order and way of life in the cosmos so the question of the mysteries of the cosmos can be answered by art form symbols ${ }^{15}[12]$. Wayang ukur Panakawan is a virtual space or depiction of a wayang character (previously an image of relief on a temple) spread in the lives of its people. The supreme conception that has pervaded every nerve in its society is manifested in the form of puppets. The existence of tangible puppets is clearly tangible with the form of carvings or carvings with lines and rhythmic fields that imitate reality in a subjective manner. The supreme power of wayang is actually not in the puppet itself, but in the conception of response and presuppositions in the minds of the people who believe in it. Wayang ukur is only a false figure of a noble conception that is trusted; this is what is called virtual space from the expression of feelings for these conceptions.

Virtual existence wasn't something dosn't real, we can see it and really feel it, not dream or imagine it. This indicates the process of releasing images from the heart, for oneself or others who see them, which presenting a subjective event in an objective symbol ${ }^{16}[11]$. Wayang ukur Sukasman is something that shows the emanation of the inner realm of its creator, an objective presentation of subjective reality and that it can symbolize something from its bathinian life. The image created has patterns and elements such as the turbulence of the creation of the creator. But the image that apear is something pure objective phenomenon. However, a form of painting remains an objectification of subjective life, and so it is in every art work. Art works are virtual spaces or virtual images of what are the conceptions known to by creator. Virtual space is a true presentation of feelings.

\section{Conclusion}

Wayang ukur Sukasman is proof is an anthropology, sociology and aesthetics symbol. Wayang ukur Sukasman is a symbol of art, a symbol of all noble conceptions. The basis of

\footnotetext{
14 S. Langer, "Feeling and Form: The Theory of Art," Aesthet. A Compr. Anthol., pp. 317-326, 1953.

15 D. Saragi, "Dimensi Simbolik Patung Megalitik Batak: Kajian Menurut Konsep Estetika Susanne Knauth Langer," Humaniora, vol. 23, no. 3, pp. 336-346, 2011.

${ }^{16}$ S. Langer, "Feeling and Form: The Theory of Art," Aesthet. A Compr. Anthol., pp. 317-326, 1953
} 
artistic creation is what he calls "primary illusion". Primary illusion is a kind of background or screen on which various forms of art can be projected as "secondary illusions". Therefore, art works are called Langer as "virtual space." The supreme conception that has pervaded every nerve in the creator is visualized in the form of a puppet measure. wayang ukurimitates reality in a subjective manner, it is called objectivity of subjectivity. wayang ukuris a form of the symbol of expression created for people's perception through imaging. The thing that is expressed is human feelings that are able to capture phenomena that are difficult to express.

\section{References}

[1] B. Sabunga, D. Budimansyah, and S. Sauri, "Nilai-nilai Karakter dalam Pertunjukan Wayang Golek Purwa," J. Sosio Reli., vol. 14, no. 1, pp. 1-13, 2016.

[2] S. M. Kushendrawati, "Wayang Dan Nilai- nilai Etis : Sebuah Gambaran Sikap Hidup Orang Jawa."

[3] Ribut Basuki, "Panakawan'S Discourse of Power in Javanese Shadow Puppet During the New Order Regime: From Traditional Perspective To New Historicism," K@Ta, vol. 8, no. 1, pp. 68-88, 2006.

[4] Sugiyono, Metode Penelitian Pendidikan (Pendekatan Kuantitatif, Kualitatif,dan $R \& D)$. Bandung: Alfabeta, 2011.

[5] S. Tinarbuko, Semiotika Komunikasi Visual. Yogyakarta: Jalasutra, 2009.

[6] S. Mulyono, Semar dan Filsafat Ketuhanan. Yogyakarta: Gelombang Pasang, 2005.

[7] Sunarto, Seni Gatra Wayang Kulit Purwa. Yogyakarta: Dahara Prize, 1999.

[8] E. Suyanto, S. Ve, and S. Tez, "Perbandingan Karakteristik Antara Tokoh Panakawan Wayang Kulit Purwa Gaya Yogyakarta Dengan Wayang Ukur Karya Sigit Sukasman,” Universitas Negeri Yogyakarta, Yogyakarta, 2012.

[9] S. Dosen, T. Akademi, D. Indonesia, and S. Email, "Wayang ukur karya sukasman studi ekplorasi bentuk," vol. 6, no. 1, pp. 78-93, 2011.

[10] Senawangi, Ensiklopedi Wayang Indonesia. Jakarta: Balai Pustaka, 1999.

[11] S. Langer, "Feeling and Form: The Theory of Art," Aesthet. A Compr. Anthol., pp. 317-326, 1953.

[12]D. Saragi, "Dimensi Simbolik Patung Megalitik Batak: Kajian Menurut Konsep Estetika Susanne Knauth Langer,” Humaniora, vol. 23, no. 3, pp. 336-346, 2011. 